Summer 2006

\title{
Secularization, Religiosity, and the United States Constitution
}

Christopher L. Eisgruber

Princeton University

Follow this and additional works at: https://www.repository.law.indiana.edu/ijgls

Part of the Constitutional Law Commons, International Law Commons, and the Religion Law

\section{Commons}

\section{Recommended Citation}

Eisgruber, Christopher L. (2006) "Secularization, Religiosity, and the United States Constitution," Indiana Journal of Global Legal Studies: Vol. 13 : Iss. 2 , Article 5.

Available at: https://www.repository.law.indiana.edu/ijgls/vol13/iss2/5

This Symposium is brought to you for free and open access by the Law School Journals at Digital Repository @ Maurer Law. It has been accepted for inclusion in Indiana Journal of Global Legal Studies by an authorized editor of Digital Repository @ Maurer Law. For more information, please contact rvaughan@indiana.edu.

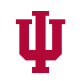

JEROME HALL LAW LIBRARY

INDIANA UNIVERSITY

Maurer School of Law
Bloomington 


\title{
Secularization, Religiosity, and the United States Constitution
}

\author{
Christopher L. Eisgruber*
}

Abstract

This article draws upon leading works in the sociology of religion to assess what I shall call "the secularization claim" regarding the United States. It endeavors, in particular; to clarify the possible meanings of "secularization," and then to use these conceptual refinements to examine what sort of evidence exists that the United States has been secularized. Though it is not possible to falsify every version of the secularization claim, there is little evidence to support it, especially in its most prominent and politically relevant variations. The article then goes on to offer a preliminary analysis of to what extent, if any, are constitutional factors responsible for sustaining a public culture in the United States that is, by comparison to most other nations, durably religious. The article identifies four constitutional or quasi-constitutional factors that sociologists and political scientists have suggested might be partly responsible for the vigor of American religion: disestablishment, the fragmentation of political authority, ethnic diversity and immigration, and provocative judicial decisions. The article concludes by recommending that scholars who are interested in the conditions that sustain religious activity and other forms of civic association in the United States should pay more attention to the constitutional fragmentation of political authority.

\section{The Secularization Claim}

Viewed by comparison to Europe, Canada, or most other nations in the developed world, the United States is strikingly religious. From the standpoint of comparative constitutional analysis, the most obvious question to ask about religious practice in the United States-and, as we shall see, the one that most sociologists have asked-is why the nation remains so robustly religious. Yet, American politicians, pundits, and legal scholars have worried a great deal about more or less the opposite question. They have declared that the United States has become significantly more secular, and they have asked why. More

*University Provost, Laurance S. Rockefeller Professor of Public Affairs \& the University Center for Human Values, Princeton University; eisgrube@princeton.edu. 
specifically, they have argued about whether the Supreme Court and constitutional law might be partly responsible for the change.

This trend was especially prominent during the 1980s and 1990s, when several much-discussed academic critiques of American law and society accused the Supreme Court of participating in an unjustified but effective campaign to secularize the United States. For example, in his popular book The Culture of Disbelief, Stephen Carter contended that "in the public square, religion is too often trivialized, treated as an unimportant facet of human personality, onc easily discarded, and one with which public-spirited citizens would not bother." Carter blamed various causes, including the Supreme Court's transformation "of the Establishment Clause ... into a guarantor of public secularism" that can be "used to disable religious groups from active involvement in the programs of the welfare state, or, for that matter, from active involvement in the public square that is the crucible of public policy." Mary Ann Glendon, in a pair of articles coauthored with Raul Yanes, alleged that the Court has "lent its prestige and sponsorship to a controversial secularizing program"3 and that the Court has become a "collaborator, witting or unwitting, of the cultural forces bent on secularizing America." Richard John Neuhaus bemoaned the creation of a "naked public square," from which religious discourse has been banished, and he laid some blame upon the Court. ${ }^{5}$ Many of these claims were metaphorical or ambiguous about the Court's role, but some of its critics were quite blunt. In a 1993 Emory Law Journal article, for example, Professor William Wagner declared that the Supreme Court's "mode of First Amendment interpretation initiated in 1947" was a "proximate cause" for the "secularization' of American culture that has occurred since the Second World War."

1. Stephen L. Carter, The Culture of Disbelief: How American law and Politics Trivialize Religious Devotion xv (paperback ed. 1994).

2. Id. at 122-23.

3. Mary Ann Glendon \& Raul F. Yanes, Structural Free Exercise, 90 Mich. L. Rev. 477, 485 (1991).

4. Raul F. Yanes \& Mary Ann Glendon, Religion and the Court 1993, First Things, Nov. 1993 at 28,30 .

5. Richard John Neuhaus, The Naked Public Square: Religion and Democracy in AmerICA $26,80-82,271$ n.5 ( 2 d ed. 1986).

6. William J. Wagner, "The Just and the Holy Are One": The Role of Eschatology in Harold Berman's Vision of Normative Jurisprudence, 42 EMORY L. J. 1045, 1047-48 (1993) (reviewing HaroLd J. Berman, Faith and Order: The Reconciliation of Law and Religion (1993)). 
Claims of this kind have subsided with the advent of the overtly religious Bush presidency. Remarkably, they have not disappeared. ${ }^{7}$ Even if they had, the concerns about secularization expressed by Carter, Glendon, Neuhaus, and others during the 1980s and 1990s would remain important because they provide many people with a conceptual frame for understanding more recent developments. For these observers, the overtly religious character of American politics today proves not that legal scholars' claims about secularization were mistaken, but that the United States has changed course (for better or for worse, depending on one's perspective) and experienced a kind of religious revival. On this view, the religious characteristics of American culture appear markedly unstable, careening from one extreme to another depending upon what the $\mathrm{Su}$ preme Court decides or who is elected president. The resulting picture of American public religion has consequences for both normative and descriptive analysis. From a normative perspective, if ordinary political decisions can swing the culture from secular to religious or vice-versa, then one might wish to take these impacts into account when evaluating judicial rulings, congressional policies, or electoral choices. From a descriptive perspective, the idea that American culture changes rapidly from religious to secular and back encourages scholars to explain why American religiosity is unstable rather than why the nation has been durably religious.

For these reasons, claims that the United States has been "secularized"-or that it was "secularized" in the 1980s and 1990s_continue to deserve critical scrutiny. This article draws upon leading works in the sociology of religion to assess what I shall call "the secularization claim"-the claim, propounded by Carter, Glendon, Neuhaus, and others, that the Supreme Court has helped to secularize some aspects of American public culture or public discourse. It endeavors, in particular, to clarify the possible meanings of "secularization," and then to use these conceptual refinements to examine what sort of evidence exists that the United States has been secularized in a way that might have been affected by Supreme Court decisions. Though it is not possible to falsify every version of the secularization claim, there is little evidence to support it, especially in its most prominent and politically relevant variations. The article then goes on to offer a preliminary analysis of what seems the more important question, once one puts aside the misleading image of a culture that veers rapidly between reli-

7. See, e.g., Julia Duin, Religion Under a Secular Assault - Commandments Suits Latest Fight, Wash. Times, Apr. 13, 2005, at Al. 
gious and secular extremes: namely, to what extent, if any, are constitutional factors responsible for sustaining a public culture in the United States that is, by comparison to most other nations, durably religious? The article identifies four constitutional or quasi-constitutional factors that sociologists and political scientists have suggested might be partly responsible for the vigor of American religion: disestablishment, the fragmentation of political authority, ethnic diversity and immigration, and provocative judicial decisions. The article concludes by recommending that scholars who are interested in the conditions that sustain religious activity and other forms of civic association in the United States should pay more attention to the constitutional fragmentation of political authority.

\section{Four Meanings of "Secularization"}

People often use the concept of secularization casually, as if its meaning were self-evident. The term is, however, ambiguous. José Casanova, a comparative sociologist of religion, distinguishes among three versions of secularization. ${ }^{8}$ The "differentiation hypothesis" maintains that religion has ceased to be the single and pervasive organizing structure for society, and has become (or is becoming) one of multiple, specialized social subsystems, each of which has its own place in society and none of which can be said to organize all the rest. ${ }^{9}$ The "decline hypothesis" maintains that religious practices are waning: in particular, that people are becoming less inclined to identify themselves as religious or to participate in religious rituals and institutions. The "privatization hypothesis" maintains that religion is becoming a private affair of diminishing public significance.

Casanova interprets the "privatization hypothesis" as having two branches, which I will analyze separately. ${ }^{10}$ What I shall call the "inner secularization hypothesis" maintains that the content of religious belief is being drained of its distinctive character, so that there is little difference between religious and secular belief systems. The "marginalization hypothesis" asserts that religious institutions and arguments are being excluded from political and social decisionmaking processes. We thus have four distinct concepts of secularization: differentiation, decline, inner secularization, and marginalization. One of them - differentiationhas undoubtedly occurred in the United States. The evolution of American higher

8. José Casanova, Public Religions in the Modern World 19-20 (1994).

9. Id. at 19, 20-25. See also Kenneth D. Wald, Religion and Politics in the United States 4 (4th ed., Rowman \& Littlefield Publishers 2003).

10. See Casanova, supra note 8 , at 35-36. 
education is illustrative. Religion and higher education were once highly interconnected in the United States; they now function as distinct social systems. Writing in 1968, Christopher Jencks and David Riesman observed that "while the Protestant clergy dominated American higher education from the founding to the end of the Civil War, their role has diminished steadily since then and is today hardly consequential for the system as a whole." "It would, however, be eccentric to attribute developments of this kind to the courts or, for that matter, to any distinctive feature of the American constitutional system. Indeed, Casanova describes differentiation as "a ...trend that serves to define the very structure of modernity."'2 Even critics such as Carter and Neuhaus seem to recognize that religion's role in modern society is limited by the functional boundaries that differentiate social systems. ${ }^{13}$ When these critics complain about secularization, they must have in mind something other than differentiation: they must have in mind some version of decline, inner secularization, or marginalization. The next three sections of this paper examine whether there is evidence that any of these forms of secularization have occurred in the United States.

\section{Have Rates of Religiosity Declined?}

At first glance, there seems to be little evidence that religious belief has declined in the United States. "Over the past fifty years of research, the percentage of Americans who believe in God has never dropped below 90\%." I+ According to 1998 Gallup Poll results, 69 percent of Americans regard themselves as members of a church or synagogue; $;^{15} 40$ percent reported that they had attended

11. Christopher Jencks \& David Riesman, The Academic Revolution 312 (1968); see also George Marsden, The Soul of the American University: From Protestant Establishment to Established Nonbelief 3-5, 265 (1994).

12. Casanova, supra note 8 , at $39,212-213$.

13. Carter says that his chief concern is that "[i]n holding, as we must, that religion is part of the purely private arena that the state must never disrupt, we run the risk of disabling the religiously devout from working seriously in the realm of policy." CARTER, supra note 1, at 21 (emphasis added). Neuhaus says that "[c]rucial to ... a democratic order is a public square in which there are many actors.... The several actors in the public square-government, corporations, education, communications, religion-are there to challenge, check, and compete with one another." Neuhaus, supra note 5, at 84.

14. George Gallup, Jr. \& D. Michael Lindsay, Surveying the Religious Landscape: Trends iN U.S. Beliefs 23 (1999).

15. Id. at 13 
church within the past week; ${ }^{16}$ and 65 percent believed that "religion can answer all or most of today's problems." ${ }^{77}$ In response to a 1996 Gallup Poll, 47 percent of Americans said that they read the Bible at least once a week; almost half of that group (21 percent of all Americans) said that they read the Bible at least once a day. ${ }^{18}$ A 1993 poll revealed that 95 percent of Americans said that they prayed "to a supreme being," ${ }^{19}$ and 75 percent of Americans said that they prayed at least once a day. ${ }^{20}$ In general, these numbers remained relatively steady (or increased) from the 1960 s to the $1990 \mathrm{~s} .^{21}$ As Robert Putnam says, "Imleasured by the yardstick of personal beliefs, Americans' religious commitment has been reasonably stable over the last half-century-certainly much more so than one might assume from some public commentary about the secularization of American life."22

Nevertheless, the numbers are down from peaks in the fifteen years following World War II. For example, Gallup results indicated that 76 percent of Americans claimed to be church members in 1946; the number was 73 percent in 1937 and has hovered around 69 percent since $1980 .{ }^{23}$ According to Gallup, in 1958, 49 percent of poll respondents claimed that they had attended church within the past week. That rate is the high-water mark; since 1972, the number has remained level at around 40 percent..$^{2+}$ Moreover, while poll results paint a picture of durable religious commitment in the United States, they may be misleading. In an often-cited study, C. Kirk Hadaway, Penny Long Marler, and Mark Chaves compared poll results about church attendance to actual attendance counts. ${ }^{25}$ Hadaway and his coauthors estimate that "the churchattendance rate is probably one-half what everyone thinks it is." ${ }^{26}$ Of course, if we are interested in whether religion has declined in the United States, the rele-

16. Id. at 15

17. Id. at 20.

18. See id. at 50 .

19. Id. at 46.

20. See id.

21. See id. at 7-20.

22. Robert D. Putnam, Bowling Alone: The Collapse and Revival of American CommuNiTY 69 (2000).

23. GALLUP \& Lindsay, supra note 14 , at 13.

24. Id. at 15; see also Andrew Greeley, Religious Change in America 42-43 (1989).

25. C. Kirk Hadaway, Penny Long Marler \& Mark Chaves, What the Polls Don't Show: A Closer Lookat U.S. Church Attendance, 58 Am. Soc. Rev. 741-52 (1993). The key question is whether "the rate of overreporting is actually higher today" than it was in the past. Id. at 741 .

26. Id. at 750 . 
vant question is not whether people overreport church attendance, but whether the rate of overreporting has changed. Hadaway, Long, and Chaves conjecture that overreporting has increased, but there is no way to test that hypothesis. ${ }^{27}$

Leading scholars disagree about trends in American church attendance. Andrew Greeley argues that "[w]ith the exception of the dramatic Catholic change between 1968 and 1975 (an episodic event), patterns of American church attendance are remarkably stable." ${ }^{28}$ Robert Putnam, looking at more or less the same data, argues that there has been "a decline in church attendance of roughly one-third between the late 1950s and the late 1990s, with more than half of the total decline occurring in the 1960s." ${ }^{29}$ Roger Finke and Rodney Stark, relying on church-membership estimates rather than on poll data, argue that religious participation in the United States has risen steadily throughout American history. ${ }^{30}$ Finke and Stark are interested in how many Americans are church participants, not in how many attend church each week.

Church attendance is not the only measure of religious belief, and some commentators claim to have found significant evidence for the decline of religion in other statistical indicators. For example, an increasing number of American poll respondents have indicated that they had "no religion." The percentage roughly doubled, from around 3 percent to around 6 percent, between 1965 and $1975 .{ }^{31}$ Norval Glenn has argued that the increase in "no religion" responses might result from a general decline in levels of American religiositythat is, Americans in general (not just those who report "no religion") might have experienced diminishing attachments to religion, with the consequence that a growing number of Americans felt no attachment at all. ${ }^{32}$

Unambiguous evidence of decline can be found if we focus on particular groups within American society, rather than on the society as a whole. University graduates have become notably less religious than they once were. In the 1950s, "studies generally showed that college educated persons were somewhat more

27. Id. at 749-50. Putnam's book contains an excellent discussion of the controversial statistical evidence suggesting a decline in levels of church involvement among Americans. Purnam, supra note 22 , at $65-79$.

28. Greeley, supra note 24 , at 56.

29. Putnam, supra note 22, at 72.

30. Roger Finke \& Rodney Stark, The Churching of America, 1776-1990: Winners and Losers in OUR Religious Economy 274 (2005).

31. Norval D. Glenn, The Tiend in "No Religion" Respondents to U.S. National Surveys, Late 1950s to Early 1980, 51 Public Opinion Quarterly 293 (1987).

32. Id. at 300,311 (emphasis in the original). 
likely than the less educated to participate in organized religion." 33 By the 1970s, Americans with higher education were less religious than other Americans, and the trend toward secularism among the educated continued in the $1980 \mathrm{~s} .{ }^{34}$ During the same period, the proportion of Americans with higher education increased dramatically; the result, in Robert Wuthnow's words, was that "education seemed to have become associated with a kind of 'gap' in religious commitment that had not been there prior to the $1960 \mathrm{~s} .{ }^{" 35}$ On the other hand, some forms of religiositynotably, evangelical protestantism-have made gains among the college educated while other forms-such as mainline protestantism-have diminished; thus, one kind of gap between college-educated Americans and other Americans has actually narrowed over the past several decades. ${ }^{36}$

\section{Evidence of "Inner Secularization"}

For our purposes, the two versions of privatization - that is, inner secularization and marginalization-are probably the most important forms of "secularization." Most sociologists who insist that America is becoming more secular are interested, in the words of Steve Bruce, "not so much [in] 'Do people claim to be religious' but 'What difference does being religious make." ${ }^{37}$ Likewise, Carter, Glendon, Neuhaus, and others who complain about the "secularization" of American society never deny, so far as I can tell, that most Americans believe in God or that a majority attend church regularly. Instead, they contend that religion is not taken sufficiently seriously: that it is "trivialized" or "made into a hobby," as Carter says, or that it is excluded from "the public square," as Neuhaus says.

Unfortunately, "privatization" is hard to measure. That is especially so insofar as we are interested in inner secularization. Statistics leave enormous room for argument. For example, during the past four decades the number of Americans who said that they regarded the Bible as literally true has been cut in half; it was 65 percent in 1964 compared to 33 percent in $1998 .{ }^{38}$ Some sociologists take

33. Robert Wuthnow, The Restructuring of American Religion: Society and Faith Since WORLD WAR II, at 161 (1988).

34. Id. at 162,170 .

35. Id. at 170 .

36. Laurie Goodstein \& David D. Kirkpatrick, On a Christian Mission to the Top, N.Y. TIMEs, May 22, 2005, at $§ 1$, at 1 .

37. Steve Bruce, Religion in the Modern World 140 (1996).

38. Id. at 144; Gallup \& Lindsay, supra note 14, at 35. 
this change to be dramatic evidence of secularization, ${ }^{39}$ but $\mathrm{Greeley} \mathrm{hypothesizes}$ that it can be explained as the consequence of changes in Catholic theology connected to Vatican II. ${ }^{40}$

Bruce makes much of poll data about attitudes of evangelical Christian youth. In 1951, 77 percent of these young people said that playing cards was "morally wrong all the time," 91 percent of them felt that way about waltzing, 46 percent about "attending 'Hollywood-type' movies," and 98 percent about drinking alcohol. By 1982, none (zero percent) of the youth said that playing cards or waltzing or attending 'Hollywood-type' movies was "morally wrong all the time"; only 17 percent took that position about drinking alcohol. Indeed, in 1982,55 percent of evangelical youth thought that "heavy petting" was occasionally permissible in dating relationships-a statistic for which no 1950 s comparison is possible, because (according to Bruce) it would have been unthinkable that any evangelical Christian would condone such behavior and hence pollsters did not ask. ${ }^{+1}$

Bruce suggests that these changes show that "evangelicals have abandoned a lot of their social distinctiveness" 42 and have thus become more secular. Perhaps so, but another interpretation is possible: rather than supposing that evangelical Christians have assimilated into the American mainstream, we might suppose that evangelicals remain equally far removed from the "mainstream," but that the "mainstream" itself has shifted. Card playing (to say nothing of waltzing!) is no longer a focus of intense moral concern. Indeed, Robert Putnam cites the decline of neighborhood card games as one indication that American civil society has weakened. ${ }^{43}$

Statistics aside, there is a body of more impressionistic research suggesting that modern American religious belief is sometimes shallow or self-centered or both. Thus Robert Bellah and his research team called attention to one of their interview subjects who "actually named her religion (she calls it her 'faith') after herself." According to "Sheila Larson" (a pseudonym devised by the Bellah team), her faith was "my own Sheilaism"; it was "just my own little voice" which urged her to, among other things, "love yourself and be gentle with yourself."

39. See, e.g., Bruce, supra note 37, at 138; GlenN, supra note 31, at 311.

40. GreEley, supra note 24 , at 18-19.

41. Bruce, supra note 37, at 148-49. The data is from James Davison Hunter, Evangelicalism: The Coming Generation 59 (1987).

42. BRUCE, supra note 37 , at 149.

43. Putnam, supra note 22, at 102-05. 
Bellah and his coauthors believe that Sheilaism "suggests the logical possibility of over 220 million American religions, one for each of us," making American religion "private and diverse" where it was once "public and unified."

Critics of the "inner secularization" hypothesis allege that it exaggerates both the shallowness of modern-day American religion and the profundity of its antecedents. ${ }^{45}$ Greeley contends that the "inner secularization" hypothesis depends upon a dichotomy which holds that "either American religion is authentic, prophetic, and challenging or it is inauthentic, culture-supporting, and comforting." ${ }^{+6}$ The dichotomy is a false one: today and throughout American history, "both dimensions of religion [will] almost certainly coexist both in their pure forms and in many admixtures of the two." ${ }^{" 7}$ Greeley and political scientist Kenneth Wald emphasize two careful ethnographic analyses of Muncie, Indiana, done fifty years apart: the famous "Middletown" study of Muncie, Indiana, published by Robert S. Lynd and Helen Merrell Lynd in 1929, and a follow-up study in the 1970 s. $^{48}$ The follow-up study found that there had been some "growth of religious tolerance, but little else had changed since the 1920s." ${ }^{\prime \prime}$ Moreover, Roger Finke and Rodney Stark present compelling evidence that throughout American history-including recent decades-the most demanding religions have grown in size while less demanding, more secularized churches have lost membership..$^{50}$

Yet, as Greeley concedes (with obvious dissatisfaction), the "inner secularization" hypothesis "cannot be falsified." By the same token, it cannot be verified. It is hard to measure the strength of "inner beliefs," and is still more difficult to compare such beliefs across generations. We must therefore concede that "inner secularization" might have occurred in the United States. If "inner secularization" has taken place, it is possible to devise theories that attribute some responsibility for the phenomenon to the Supreme Court. So, for example,

44. Robert N. Bellah et al., Habits of the Heart: Individualism and Commitment in American Life 220-21 (1996); see also, e.g., Wade Clark Roof, Spiritual Marketplace: Baby Boomers and the Remaking of American Religion (1999).

45. WALD, supra note 9, at 10-17; GREELEY, supra note 24, at 117-21.

46. GreELEY, supra note 24 , at 119.

47. Id.

48. See generally Theodore Caplow et al., All Faithful People: Change and Continuity in Middletown's Religion (1983).

49. WALD, supra note 9 , at 13.

50. See Finke \& Stark, supra note 30, at 42-43, 238, 249-255, 275.

51. Greeley, supra note 24, at 119. 
Bellah's account of "inner secularization" connects it with the rise of rightsoriented individualism in the United States, ${ }^{52}$ and one might in turn blame the Supreme Court's doctrine or rhetoric for stoking America's enthusiasm for rights.

This sort of causal story is untestable. The best we can do is to notice two features of the "inner secularization" hypothesis which cast doubt upon claims that Supreme Court decisions, or any other recent constitutional choices, are root causes. The first pertains to the timing of the phenomenon. Complaints about the shallowness of American religion are nothing new. For example, in Will Herberg's 1955 classic, Protestant-Catholic-Jew: An Essay in American Religious Sociology, the author laments that "the religiousness characteristic of America today is very often a religiousness without religion, a religiousness with almost any kind of content or none, a way of sociability or 'belonging' rather than a way of reorienting life." 53 Perhaps Herberg was wrong, or perhaps the "inner secularization" phenomenon has grown increasingly acute. But if "inner secularization" dates back to 1955 (or before), it would be implausible to assign a significant causal role to the Supreme Court's Establishment Clause doctrine (which was launched in 1947) or even to its individual rights jurisprudence in general (which was then in its infancy).

Timing aside, the "inner secularization" hypothesis was formulated within sociological theory by Thomas Luckmann and others to describe the effects of modernization (not of particular court decisions or constitutional choices) in any society (not just the United States). In particular, Luckmann believed that "inner secularization" was a consequence of social differentiation: once religion became one sphere among many others, religion necessarily was reduced to one of many roles assumed by the autonomous self. ${ }^{54}$ If "inner secularization" is an inevitable consequence of modernity, then, obviously, it will not be much affected by Supreme Court jurisprudence-or, for that matter, by any other mainstream political choices. Of course, Luckmann might be wrong. But, at a minimum, his theory provides an alternative explanation for "inner secularization," one that is consistent with the trajectory of religious belief in Europe and Canada, as well as in the United States.

52. BellaH ET AL., supra note 44 , at 143-44.

53. Will Herberg, Protestant-Catholic-Jew: An Essay in American Relicious Sociology 260 (1960).

54. Casanova, supra note 8 , at 35-37. For Luckmann's seminal book, see generally Thomas Luckmann, The Invisible Religion: The Problems of Religion in Modern Society (1967). 


\section{The Social and Political Power of American Religion}

That brings us, finally, to the marginalization hypothesis: the claim that even if it has not declined numerically and regardless of whether it has undergone "inner secularization," American religion has been excluded from social and political decisionmaking processes. When commentators contend that the Supreme Court has somehow "secularized" American politics, they often seem to have "marginalization" in mind. That is certainly what worried Neuhaus when he inveighed against the "naked public square." He has written, for example, that American churches are in danger of losing their role as mediating institutions between state and society: "Once religion is reduced to nothing more than privatized conscience, the public square has only two actors in it-the state and the individual." 55 The "marginalization hypothesis" is also prominent in Carter's argument.

Despite its popularity, there is surprisingly little evidence to support the "marginalization hypothesis." Indeed, most of the evidence seems to run in the opposite direction: it suggests that religion is becoming an increasingly powerful force in American politics. Of particular importance is the spectacular growth of what Robert Wuthnow calls "religious special purpose groups." ${ }^{16}$ Like churches, these interest groups are rooted in religious concerns; unlike churches, they are "lo]rganized to accomplish explicitly focused objectives" and so "do not have to concern themselves with building churches, with running seminaries, or with rendering doctrinal interpretations." ${ }^{\text {}} 7$ Examples include the Fellowship of Christian Athletes, the Moral Majority, the Coalition on Women and Religion, the National Council of Churches, and Friends in Service Here (FISH). Religious special purpose groups may draw their membership entirely from one denomination, but, as the above examples suggest, many (if not most) are interdenominational. Religious special purpose groups have long existed in the United States (the Women's Christian Temperance Union, founded in 1874, is a notable nineteenth-century example), but Wuthnow reports that their number and influence escalated dramatically after World War II. He estimates that approximately 400 such groups existed at the war's end, that almost 200 new

55. Nevhaus, supra note 5 , at 82.

56. Wuthnow, supra note 33, at 100-31; Robert Wuthnow, The Struggle for America's Soul: Evangelicals, Liberals, and Secularism 51-54 (1989).

57. Wuthnow, supra note 56, at 51-52. 
groups had come into being by 1960, and that by the 1980s America was home to around 900 religious special purpose groups (including some very prominent ones, such as the Moral Majority). ${ }^{58}$ In Wuthnow's view, the rise of religious special purpose groups has enabled "religious people [tol become organized to participate in public affairs more effectively." ${ }^{\circ 9}$ As a result, "religion's influence may have been increasing. At least religious groups are making more collective efforts now to influence the public sphere than they did only a few decades ago."

Even if we put aside the rapid growth of religious interest groups, there remains plenty of evidence that religion's role in American public life is central rather than marginal. Religious participation correlates positively with virtually all forms of political and civic involvement, including voting. ${ }^{61}$ If we index public power by reference to money rather than participation, religious organizations still look robust. Partly in consequence of their tax-exempt status, religious organizations receive and disburse large sums each year. Kenneth Wald has reported that:

In 1986, for example, Americans contributed more than $\$ 40$ billion to religious institutions, making churches by far the most favored recipient of philanthropy. Congregations devoted a significant share of that income to education, human service, health and hospitals, community development, the arts, and environmental protection... With its $\$ 1.5$ billion annual budget, Catholic Charities is second only to the U.S. government in welfare activities. ${ }^{62}$

Churches and other religious organizations compete effectively for public as well as private contributions. Despite Establishment Clause restrictions, religious institutions were major beneficiaries of federal spending long before "charitable choice" became a political issue. Stephen Monsma reports that in 1993, "65 percent of Catholic Charities' revenues came from government sources, as did 75 percent of the Jewish Board of Family and Children's Services

58. Wuthnow, supra note 33, at 112.

59. Wuthnow, supra note 56 , at 51.

60. Id. at 54.

61. WALD, supra note 9, at 35-37; PUTNAM, supra note 22, at 67.

62. WALD, supra note 9 , at 10. 
revenues, and 92 percent of Lutheran Social Ministries' revenues." ${ }^{63}$ Among private colleges and universities, "religiously based institutions ten[d] to report receiving a slightly greater proportion of their funds from government sources than did the secularly based institutions." ${ }^{\text {"t }}$ Monsma concludes that "religiously based nonprofits fully share in the public-nonprofit partnership." ${ }^{55}$ There is a single notable exception to this rule: only limited public money goes to religious elementary schools, junior high schools, and high schools. ${ }^{66}$ Religious schools appear, however, to have flourished even without subsidies. For example, according to Robert Wuthnow, Christian schools grew between 1971 and 1978 at rates that were "phenomenal: a 47 percent increase in numbers of schools, a 113 percent increase in numbers of teachers, and a 95 percent increase in enrollments. ${ }^{97}$ (Wuthnow published these claims in 1989, when the secularization claim was near the zenith of its popularity).

Religion's power is evident from, among other things, the deference paid to it by politicians. In recent presidential elections, candidates from both parties have sought to demonstrate their piety. ${ }^{68}$ George W. Bush has emphasized the importance of religion to his personal philosophy and public office, creating what one journalist has labeled "the faith-based presidency." decades ago, the sociologist Will Herberg commented that "a professed 'unbeliever' would be anathema to either of the big parties and would have no chance whatever in political life." 70 The remark rings no less true today; indeed, in the 2000 presidential election, Democratic vice-presidential candidate Joseph Lieberman declared that "our Constitution was made only for a moral and religious people" and that we should "never ... indulge the supposition "that morality can be maintained without religion."'71 Lieberman's remarks provoked a modest backlash (most notably from Jewish groups), and he eventually hedged

63. Stephen V. Monsma, When Sacred and Secular Mix: Religious Nonprofit Organizations and Public Money 1 (1996).

64. Id. at 69.

65. Id. at 70 .

66. Id. at 10 .

67. Wuthnow, supra note 33, at 198. "Eighty-six percent of all students enrolled in private elementary and secondary schools are in religiously based schools." Monsma, supra note 63, at 9 .

68. See David D. Kirkpatrick, Battle Cry of Faithful Pits Believers Against Unbelievers, N.Y. Times, Oct. 31, 2004, at 24.

69. Ron Suskind, Without a Doubt, N.Y. Times MAG., Oct. 17, 2004, at 44, 47.

70. HerberG, supra note 53, at 52.

71. Richard Pérez-Peña, Lieberman Seeks Greater Role for Religion in Public Life, N.Y. TImes, Aug. 28, 2000, at A14. 
his views, but it is not clear that he paid any political price whatsoever for slandering nonbelievers.

The statistical and other evidence of religion's social and political power in the United States seems so overwhelming that it is hard to imagine what basis there could be for worrying that religion has been "marginalized." Perhaps someone could point to changes in the way that social services are delivered. Robert Wuthnow suggests that over the last century "the state has taken over many of the welfare and educational functions formerly provided by religious organizations." 72 Does this development constitute evidence of marginalization? It might instead be characterized as an instance of differentiation: In a modern society, religion cannot expect to dominate such distinct spheres as education, welfare services, or health care. Moreover, while the welfare state's growth is obvious, religious institutions continue to be important providers of social services in the United States. According to Stephen Monsma, for example, "[a]mong all child care providers, one-third are church-based.... Among the agencies belonging to the National Association of Homes and Services to Children, roughly one-half have a clear religious base."73

Religious special purpose groups have augmented religion's role as a provider of social services much as they have increased religion's influence in politics. Faith-based service organizations now provide far more social services than do traditional congregations. ${ }^{74}$ Nevertheless, congregations also continue to deliver services. Mark Chaves, who has authored the leading scholarly study of modern American congregations, suggests that "the history of congregational involvement in social services [in the United States] is characterized more by continuity than change." 75 Chaves allows that a "smaller percentage of [charitable] work" is now being done "by congregations and other religious organizations," but he argues that the government has not taken over work previously performed by religious institutions; rather, "government and government-funded organizations began new activities, with the result that much more antipoverty work [is being] accomplished." 76

72. Wuthnow, supra note 56 , at 108.

73. Monsma, supra note 63 , at 9.

74. Mark Chaves, Congregations in America 44-93 (2004); Robert Wuthnow, Savinc America: Faith-Based Services and the Future of Civil Society 172 (2004).

75. Chaves, supra note 74 , at 87 .

76. Id. at $86-87$. 
Of course, even if religion remains a (perhaps increasingly) powerful social and political force, it may have been unfairly excluded from some government benefits. One can always argue (by reference to equality or some other principle) that the Supreme Court has enforced the Establishment Clause too rigidly. That is what Carter does, for example, when he complains that the Court has exaggerated Establishment Clause restrictions and thereby "disable[d] religious groups from active involvement in the programs of the welfare state." But Carter goes on to allege that the Supreme Court has also disabled religious groups "from active involvement in the public square that is the crucible of public policy." 77 This further allegation lacks support. From the evidence we have reviewed, it would appear that American-style disestablishment has permitted religious belief and religious organizations to flourish, and that they have been able to participate powerfully in public life. There is room for doubt, of course; in general, it is impossible to offer conclusive judgments about the kind of sociological issues addressed here. Still, if some religions and churches have (at some times) refrained from entering public political discourse, it seems more plausible to say, with Casanova, that they "voluntarily withdrew and stayed out of it for religious reasons" ${ }^{18}$ than to say that they were disabled by Supreme Court action.

\section{Assessing the Secularization Claim}

We have now surveyed the various ways in which America might have become more secular. Does the evidence provide any reason to believe that the $\mathrm{Su}$ preme Court has secularized the United States? If so, the effects are difficult to detect. "Secularization" in the sense of "differentiation" has certainly occurred in the United States. Domains such as higher education, once subject to religious control, have developed autonomous, nonreligious norms. Yet, the timing of these events makes it impossible to attribute causation to the Court, and even the Court's critics seem prepared to concede that "differentiation" is an essential feature of a modern, pluralist society. Mean while, the evidence for "decline," "inner secularization," and "marginalization" is ambiguous at best. Statistics suggest that church-going and other religious practices have remained vigorous and stable; ethnographic studies indicate that Americans today may be no less pious

77. Carter, supra note 1 , at 123.

78. Casanova, supra note 8 , at 164. 
than their predecessors; and religious organizations exercise tremendous political and social clout.

There is room for argument, however. Religious belief has declined noticeably in some important sectors of American society-most notably, among the college educated. There is statistical evidence that the level of irreligion in the United States (as measured by the fraction of Americans who say they never attend church) is rising. Claims about "inner secularization" are ultimately impossible to falsify or verify, and some respected sociologists insist that the phenomenon is real. Finally, it is possible to restate claims about "marginalization" in a nonfalsifiable form (not easily though-the evidence of religion's power and public presence is hard to deny).

If indeed secularization has occurred in the United States, it is possible-at least as a purely theoretical matter-to describe causal mechanisms through which Supreme Court decisions might have made America more secular. For example, one might claim that if the Supreme Court had not prohibited states from subsidizing religious schools, private religious schools would be (even) more numerous than they are today, and as a result religious communities would be stronger. Or that if the Supreme Court had not eliminated public school prayer, students would have become more devout. Or that the Supreme Court's focus on rights has exacerbated the individualism of American society and hence contributed to the "inner secularization" of American religion.

On the other hand, there are plenty of other possible - and, in my view, much more plausible-causes for whatever secularization has occurred in the United States. Robert Putnam blames television, commuting, suburban sprawl, the two-career family, and what he calls "generational shift" for the diminution in American civic activity (including church-going). ${ }^{79}$ Andrew Greeley points to changes in sexual morality to explain the drop in Catholic church-going. ${ }^{80}$ Robert Wuthnow attributes changes in American religious culture to, among other things, dramatic increases in the proportion of Americans receiving college education. ${ }^{81}$ These social forces (and others, including the cultural shifts brought about by wars, the feminist movement, the civil rights movement, and changing demographic patterns) seem more plausible sources of American religious change than do Supreme Court decisions.

79. Putnam, supra note 22 , at 283-84.

80. Greeley, supra note 24 , at $47-56$.

81. Wuthnow, supra note 33 , at 154-72. 
So why is the secularization claim so popular? William P. Marshall has identified a few possibilities. First, claims about secularization might be motivated by disagreement with the details of judicial doctrine or political argument. They might, in other words, be complaints about what judges or other political actors have said about American society, rather than about American society itself. ${ }^{82}$ Second, there might be what Marshall terms a "political" explanation for the secularization claim: because America is religious, complaining about "secularization" is an effective rhetorical trope. Marshall suggests that "[r]eligiously oriented political groups and movements... have been active in spreading the marginalization message for their own political benefit." ${ }^{83}$ A related, but slightly different, explanation focuses on perception rather than political strategy. People who believe that religion is exceedingly important may be inclined to worry that others do not take religion sufficiently seriously and that matters are getting worse. Ironically, then, the persistent hand-wringing about "secularization” may itself be evidence of American religion's durable social and political strength.

\section{American Religion in Comparative Perspective}

The concern with secularization has distracted constitutional theorists from studying another, potentially more productive, question: Are constitutional features of the American regime (including not only Supreme Court decisions but also structural elements of the constitutional design) in any way responsible for the absence of secularization in America? After all, comparative studies consistently suggest that the American political regime is notably hospitable to religious belief. Poll data again provide a useful, if imperfect, starting point. A 1995 poll found that only 70 percent of Canadians and 61 percent of Britons (by comparison to 96 percent of Americans) believed "in God or [a] universal spirit or lifeforce." ${ }^{84}$ A 1993 Gallup poll found that only 59 percent of Britons (as compared to 88 percent of Americans) said they "ever pray." Similar differences persist in questions that pertain to intensity of belief. For example, "among people in the United Kingdom just 17 percent of adults say they consider religion 'very important' in their lives[;

82. William P. Marshall, The Culture of Belief and the Politics of Religion, 63 LAw \& ConTemP. ProBs. 453, 460-61 (2000).

83. Id. at 461 .

84. Gallup \& Lindsay, supra note 14 , at 122.

85. Id. at 123. 
bly comparison, . . 57 percent of Americans take it very seriously. ${ }^{~} 86$ If we turn to evidence of irreligiosity, we find even more striking evidence of Europe's comparative secularism. For example, 59 percent of French poll respondents have said that they never go to church; during the last three decades this number has never exceeded 19 percent in the United States. Similar disparities exist between the United States and other European countries. ${ }^{87}$

More qualitative studies of religious belief produce results consistent with these questions about frequency of church attendance. For example, polls conducted in the United States in 1994 and in Canada in 1995 asked respondents how they viewed the Bible: as "the actual word of God ... to be taken literally," as "the inspired word of God but not everything in it should be taken literally," or as "an ancient book of fables, legends, history, and moral precepts." In both countries, the middle option ("inspired word of God") was the most popular, and it was selected by more or less the same number of respondents- 57 percent of Americans and 53 percent of Canadians. But the remainder of the populations divided very differently. 31 percent of Americans, but only 14 percent of Canadians, regarded the Bible as the literal word of God. And, conversely, 28 percent of Canadians, but only 11 percent of Americans, said that the Bible was "an ancient of book of fables," history, and morals. ${ }^{88}$

Nor are the differences confined to opinion poll data:

In the United States, the number of Bibles purchased annually per capita is more than double that in Great Britain, nearly five times as high as in West Germany, and eleven times the number in France. In the United States, one church exists for approximately every 500 people, whereas in each of the other three countries one church exists for only every 1,000 members of the population. Clergy per capita in the United States exceeds that in Great Brit-

\section{Id. at 122.}

87. Sheena Ashford \& Noel Timms, What Europe Thinks: A Study of Western European VALUES 46 (1992).

88. Gallup \& Lindsay, supra note 14, at 121. Contrasts between American and Western European data exhibit similar patterns. See Peter L. Berger, The Desecularization of the World: A Global Overvieu, in The Desecularization of the World: Resurgent Religion and World Politics 1, 9-10 (Peter L. Berger, ed., 1999) (emphasis in original); Grace Davie, Europe: The Exception that Proves the Rule?, in The Descularization of the World, supra, at 65-84; Casanova, supra note 8, at 75-91; Steve Bruce, Choice and Religion: A Critique of Rational Choice Theory 89-120 (1999). 
ain and West Germany by a ratio of two to one (and is marginally higher than in France). ${ }^{89}$

If we focus on rates of secularization, rather than levels of secularization, we get similar results. For example, in Western Europe, "there has been an increase in key indicators of secularization, both on the level of expressed belief (especially those that could be called orthodox in Protestant or Catholic terms) and, dramatically, on the level of church-related behavior-attendance at services of worship, adherence to church-dictated codes of personal behavior ..., recruitment to the clergy." 90 These trends have long been "observed in the northern countries of the continent" and since World War II they have "rapidly engulfed the south." 11 To these statistical results we may add José Casanova's observation that "among advanced Western industrial societies only in the United States has there appeared a religious fundamentalist movement of societal importance." 92

In light of this evidence, it is not surprising that sociologists compete to explain why American religion is so vigorous (especially by comparison to its European counterparts), rather than to identify forces tending to make America more secular. If we are interested in how the Constitution influences American religious practice, we would do well to invert the question most commonly asked in American law journals: Instead of asking whether the Supreme Court has secularized the United States, we should ask whether constitutional features of the United States have inhibited secularization. The next section summarizes some leading sociological theories; all of them have a constitutional or quasi-constitutional dimension.

\section{Constitutional Foundations of Religious Vigor}

\section{A. Disestablishment}

According to Casanova, "the United States represents the paradigmatic and historically first model of the separation of church and state." Although ordi-

89. Wuthnow, supra note 56 , at 50.

90. Berger, supra note 87 , at 9-10.

91. Id. at 10. For further discussion of continental European examples, see, e.g., Davie, supra note 87 , at 65-84; CASANova, supra note 8, at 75-91; BRUce, supra note 87, at 89-99. On Britain in particular, see Bruce, supra note 37, at 29-37; Bruce, supra note 87, at 61-88; Steve Bruce, Religion in Modern Britain 29-71 (1995).

92. Casanova, supra note 8 , at 135.

93. Id. at 71. 
nary citizens and even law professors sometimes worry about whether disestablishment hinders religion, sociologists usually suppose that American-style disestablishment contributes to religious vitality. Alexis de Tocqueville famously emphasized that if religion affiliated itself with the state, its power and prestige would suffer from association with policies that were unsuccessful or transitory. ${ }^{9+}$ Roger Finke and Rodney Stark are among the most sophisticated modern exponents of the position. They amplify Tocqueville's case in terms drawn from rational choice theory. Finke and Stark maintain that a free market in religion permits suppliers to generate and market the religious "product" that will most satisfy the needs of consumers. ${ }^{95}$ Established churches are "monopolists" and therefore exhibit two predictable deficiencies. First, "a single faith cannot shape its appeal to suit precisely the needs of one market segment without sacrificing its appeal to another." ${ }^{96}$ More specifically, no single church can be "at once worldly and otherworldly, strict and permissive, exclusive and inclusive, while the market will also contain distinct consumer segments with strong preferences on each of these aspects of faith." ${ }^{97}$ Religious pluralism can therefore satisfy a larger portion of the population than can religious establishment. ${ }^{98}$ Second, "[M]onopoly firms always tend to be lazy." When a religious organization depends upon support from the government, its leaders have an incentive to please politicians and bureaucrats rather than to cultivate the religion's membership. ${ }^{100}$ For that reason, some religious leaders have worried that President George W. Bush's faith-based initiatives, which would provide state support to religious service providers, will damage American religious institutions. ${ }^{101}$

\section{B. Fragmentation of Government Power}

Finke and Stark tend to assume that people turn to religious institutions to get a distinctively religious benefit, such as personal salvation, consolation, or moral

94. Alexis de Tocqueville, 1 Democracy in America 297-301 (J.P. Mayer ed., George Lawrence trans., 1969); see also CASANova, supra note 8, at 29, 70.

95. Finke \& STARK, supra note 30, at 17-21, 252-55.

96. Id. at 19.

97. Id. at 18 .

98. Id.

99. Id. at 19.

100. Id. at 19, 39, 59-66; CASA Nova, supra note 8, at 22.

101. Laurie Goodstein, Bush's Charity Plan is Raising Concerns for Religious Right, N.Y. TIMes, Mar. 3, 2001, at Al. 
and spiritual guidance. If that were so, then the vitality of religious practice might depend almost entirely upon whether churches were free to produce and "market" the kind of religion that adherents demanded: Disestablishment would create a "religious free-market" in which (almost) everybody who wanted religion could find a faith to his or her liking. But it is easy to imagine other interests that might lead people to join or abandon churches. For example, people might join churches in order to obtain social services or acquire political clout.

Several social scientists have accordingly suggested that the comparative vigor of American religion is partly attributable to the dispersion of political power in the United States. Government power is shared at the national level among the two houses of Congress, an independently elected president, moreor-less independent agencies, and an independent judiciary. Political power "is further subdivided among at least three separate levels of government (national, state, and local)." 102 The decentralization of American political power is "reinforced by a tradition of popular sovereignty that limits the authority of national party leaders." 103 The result is a system with numerous "entry points" and "veto points": In other words, there are many independent actors with the capacity to make policy or block its development.

This fragmentation of power has at least two important consequences for religious institutions. First, insofar as the government's veto points render it unlikely to supply satisfactory social services (such as hospitals, schools, child care, and welfare services), people will look to private institutions, including churches, to fill the void. Second, the complex structure of American government means that private groups, including churches and religious special purpose groups, will have multiple opportunities to affect policy. For that reason, as Kenneth Wald notes, "political scientists have long recognized [that] the complex structure of the U.S. government encourages groups to undertake political activity." 104 If religious groups can provide needed social services, or if they can effectively lobby the government, people will have additional reasons to affiliate with such groups.

Wald suggests that anti-abortion religious groups were more successful in the United States than in Canada because of "the many avenues of attack provided by the complex and multifaceted U.S. system of government." ${ }^{105}$ By con-

102. WALD, supra note 9 , at 31 .

103. Id.; see also Steve Bruce, Conservative Protestant Politics 158-64 (1998).

104. WALD, supra note 9, at 31 .

105. Id. at 32 . 
trast, the Canadian parliamentary system "offered the opponents of liberalized abortion few opportunities to challenge official policy." For example, "the criminal code was the exclusive responsibility of the national government," so "the provincial authorities and local governments could do little to restrict the availability of abortion services." 100

Wald supplies another example involving more pedestrian issues. He quotes a Gainesville, Florida, newspaper story about an elderly woman who lost electrical service when a tree fell on her property during a storm. She sought help from the public utility, the government, and her church. "By the time the public officials had begun to investigate the situation, the church had sent over volunteers to repair the damage and to look after the woman until family members could arrive to help." ${ }^{107}$

To similar effect, Steve Bruce emphasizes the consequences of local government autonomy, which enables religious groups to "recreate at a local level the degree of cultural homogeneity that is needed to sustain the "church' form of religion." 108 It matters that "[i]n the USA, education is a state and county matter" so that "[c]ultural groups which are strong in particular regions can ensure that their values are respected." 109 Moreover, "[i]n Europe it is very difficult to set up an independent school; it is very easy in the USA." ${ }^{110}$ Finally, "[f]ederalism encourages cultural groups to use elections" because, even if they cannot win the national level, they may have considerable clout in local elections. ${ }^{111}$

Fragmentation is much less popular than disestablishment as an explanation for the vigor of American religion, but it may be an equally important variable. If Finke and Stark or Tocqueville are correct, then what matters most about disestablishment is that it promotes competition among religions. Establishment can frustrate competition in at least three ways: directly, by prohibiting all but the "one true faith"; indirectly, by creating a single church (or set of churches) which, as a result of their enormous wealth or their political influence,

106. Id. at 32-33; see also id. at 124-38.

107. Id. at 22 n. 10 .

108. Bruce, supra note 37 , at 142.

109. Bruce, supra note 102, at 159.

110. Bruce, supra note 37 , at 143. It bears mention that, according to Wuthnow, the growth of Christian schools between 1971 and 1978 was phenomenal: "a 47 percent increase in numbers of schools, a 113 percent increase in numbers of teachers, and a 95 percent increase in enrollments." WuthNow, supra note 33, at 198.

111. BRUCE, supra note 102, at 160; see also Richard C. Schragger, The Role of the Local in the Doctrine and Discourse of Religious Liberty, 117 HaRv. L. Rev. 1811 (2004). 
are uniquely capable of supplying what their members want and so squeeze out other faiths; or, again indirectly, by providing all churches with an incentive to serve the state rather than their congregations. Yet, barriers of the first, direct kind are rare in first-world countries. If only the indirect effects of establishment matter, and if (as Finke and Stark argue) nonestablished faiths are better able to serve members than established ones, then the most crucial question is not whether established churches exist but whether nonestablished churches can organize and operate effectively when needed. Government fragmentation makes it easier for new, small churches to have an impact, and hence increases the likelihood of religious competition-regardless of whether one or more faiths are receiving government subsidies.

\section{Ethnic Diversity and Immigration}

Another explanation for American religiosity focuses on ethnic diversity and the immigrant character of American society. Two early and influential accounts of the relationship between ethnic identity and American religious practice were H. Richard Niebuhr's The Social Sources of Denominationalism, published in 1929, and Will Herberg's Protestant-Catholic-Jew, first published in 1955. Herberg argued that "it is as members of a religious group that the great mass of Americans identify themselves to establish their social location once they have really sloughed off their immigrant foreignness." 112 Whereas immigrants were expected to give up their language and embrace many American values, "the religion of the immigrants-with certain necessary modifications, such as the replacement of the ethnic language by English - was accorded a place in the American scheme of things that made it at once both genuinely American and a familiar principle of group identification." 113 This process of identification is important not only to new immigrants but to descendants who want 'to recover [their] 'heritage,' so as to give [themselves] some sort of 'name,' or context of self-identification and social location in the larger socicty." 14 "Self-identification in religious terms" promotes institutional forms of religious activity: "It engenders a sense of adherence to a church or denomination and impels one to institutional affiliation." 115

112. Herberg, supra note 53, at 38 .

113. Id. at 31 .

114. Id. at 257 .

115. Id. 
The details of Herberg's argument are dated, but the general themes remain powerful. In the United States, religious institutions provide sources of personal support, political organization, and social community for ethnic minorities, including communities of new immigrants. "One reason why Americans are religious is that their churches offer them a way in which they can display their commitment to American values while maintaining their ethnic distinctiveness." 116 This phenomenon is not unique to new immigrants; the strength of African-American churches is a powerful example of how religious institutions can sustain groups that feel excluded from mainstream American culture and politics. Conversely, religious affiliations also provide a way for mainstream or privileged groups to claim prestige: they could exclude outsiders and thereby entrench their own social position. ${ }^{117}$

\section{Provocative Court Decisions}

Finally, some sociologists have proposed that controversial Supreme Court decisions have helped to catalyze the formation of religious special purpose groups and hence to increase religion's power and presence in political arenas. Robert Wuthnow points out, for example, that Protestant leaders formed Americans United for the Separation of Church and State in reaction to Everson v. Board of Education, ${ }^{118}$ which upheld the constitutionality of public subsidies for the bus fares paid by students traveling to and from Catholic schools. ${ }^{119}$ Religious groups organized on both sides of the school prayer issue after Engel $\nu$. Vitale, ${ }^{120}$ which prohibited states from sponsoring prayers in public schools. ${ }^{121}$ Steve Bruce believes that the school prayer decisions helped to reinforce the importance of public prayer to religious Americans; he notes that, in contrast, Britain has continued to permit prayer in its schools, but the ritual has quietly faded into irrelevance. ${ }^{122}$

The Court's share of responsibility for these developments is not easy to assess (I am myself skeptical about whether the Court decisions had much independent

\footnotetext{
116. Bruce, supra note 37 , at 135.

117. See id.

118. Everson v. Bd. of Educ., 330 U.S. 1 (1947).

119. WuthNow, supra note 33 , at 115.

120. Engel v. Vitale, 370 U.S. 421 (1962).

121. Wuthnow, supra note 33 , at 115.

122. BRUCE, supra note 37 , at 153; see BRUCE, supra note 102, at 158.
} 
causal significance; I mention them in order to render the sociological literature more faithfully, not to endorse the hypothesis). Kenneth Wald notes that "[a]s is often the case in political and legal change, the consciousness of the Court was shaped by intensive grassroots political activity that raised the church-state issue to a high place on the national agenda." ${ }^{23}$ He reports that "[t]hroughout the era of judicial activism on the church-state question, the churches, allied groups of laypersons, and interfaith organizations functioned much as classic interest groups-designing legislation, raising public support in well-orchestrated campaigns for public opinion, lobbying legislatures and courts, and bringing and defending lawsuits." 124 If so, then courts are not in any simple sense the cause of religious interest-group activity; they are instead part of a feedback loop in which interest groups beget lawsuits, which in turn beget more interest groups, and so on. In any event, the details of the Court's position apparently mattered less than the fact that the Court took a position: Religious interest groups originated in response to decisions that upheld legislative discretion (as Everson did) as well as ones that limited it (as Engel did), and they organized on both sides of these cases.

\section{Fragmentation and Civic Association}

Thus far, we have discussed secularization and religiosity without examining their relationship to other, nonreligious forms of civic activity and association. That focus can be misleading. The ideas and explanations proposed in the preceding section help to illuminate the structure of American civil society in general, not just its religious components. In particular, the fragmentation of political authority under the United States Constitution deserves greater attention from students of constitutional design, both in the United States and elsewhere. Fragmentation plays a largely unappreciated role in securing liberty and in shaping the character of American citizens and American public life. We may generalize the idea of fragmentation beyond its usage in the last section, so that it encompasses not only the dispersion of power among numerous political institutions but also disestablishment and ethnic diversity. Each is a feature of the American regime that tends to inhibit the rise of a single, dominant social or political authority. The fragmentation of authority means that there is no bully capable of smothering its rivals. Put in more affirmative (and I think more

123. WALD, supra note 9 , at 111.

124. Id. 
illuminating) terms, fragmentation means there will always be a variety of constituencies and institutions to which new initiatives can appeal for support and assistance.

We have seen how these various kinds of fragmentation create conditions favorable to the formation and flourishing of religious groups. Interestingly, similar considerations may help to explain the strength of American universities. In their marvelous book on American higher education, Christopher Jencks and David Reisman observed that whereas "Britain has not allowed independent entrepreneurs, either public or private, to establish new colleges and universities... in America ... central authority has been weaker and more distrusted." 125 Educational innovators in the United States consequently had options not enjoyed by their British counterparts. Thus, "the dissidents who disliked Harvard, Yale, or William and Mary did not in most cases try to transform them, as English dissidents did Oxford and Cambridge during the same era. Instead, they set up their own competitive colleges to serve new purposes, many of which had not previously been regarded as appropriate for a college."126 Moreover "since colonial times states and cities have been unhappy about depending on colleges located beyond their physical and cultural boundaries," and as a result "[a]ll states and many cities have therefore set up their own institutions "responsive to local conditions." 127 According to Jencks and Reisman, "nobody even considered the possibility that several states should be required to collaborate in establishing landgrant colleges." ${ }^{128}$ Not only the fragmentation of American government into multiple units, but also the diversity of American society, spurred the proliferation of colleges: "Nineteenth-century Americans grouped themselves by occupation, social class, religion, sex, locality, and ethnic background," and "almost all these groups felt impelled to set up their own colleges, both to perpetuate their distinctive sub-culture and to give it legitimacy in the larger society." 129

Ironically, then, churches and universities, which sometimes regard one another as rivals, may owe their vigor to similar sources. We should not exaggerate the point, of course. Infusions of federal money accelerated the trend toward professionalization of university faculties. ${ }^{130}$ In higher education, unlike in

125. Jencks \& Riesman, supra note 11 , at 105.

126. Id. at 2.

127. Id. at 155 .

128. Id. at 157.

129. Id. at 2-3.

130. Id. at $14-15,267-68$. 
American religion, old institutions dominate, and new entrants face huge handicaps. New colleges and universities do form, but they cannot easily compete with their well-established predecessors. ${ }^{131}$

None of this, though, is inconsistent with the idea that fragmentation of American authority (both social and political) has been as crucial to higher education as to religion. Indeed, the higher education example makes clear that fragmentation is an idea much different from "deregulation" or "the night watchman state." Fragmentation is quite consistent with the idea of government intervention-although it entails that intervention is likely to come from multiple, competing governmental bodies, and that this uncoordinated intervention will rarely be capable of dominating any sphere of associative activity. Thus, for example, states (and even localities) have competed with one another to produce the best universities, and federal funding for research has piggy-backed on competition among both public and private faculties.

Nor are the religious and collegiate domains unique. For example, Russell Hardin has suggested that the weakness of national policymaking institutions enabled economic markets to thrive (because they were insulated against the destabilizing effects of policy shifts), ${ }^{132}$ and I have elsewhere argued that the fragmentation of state and national government in the United States leaves local institutions with more autonomy than they would otherwise have. ${ }^{133}$ The same structural features of American government which cripple efforts to devise and implement national policies (about, for example, health care) are uniquely hospitable to the associational activity-religious, collegiate, economic, and politicalfor which America is known. It is an open question whether that trade-off is a desirable one-but surely its advantages and disadvantages ought to be better understood.

131. See Wuthnow, supra note 56 , at 164.

132. See Russell Hardin, Liberalism, Constitutionalism, and Democracy 237-38 (1999). Hardin credits Tocqueville with the basic insight.

133. See Christopher L. Eisgruber, Constitutional Self-Government 93-95 (2001). 